\title{
Linomide Prevents the Lethal Effect of Anti-Fas Antibody and Reduces Fas-mediated Ceramide Production in Mouse Hepatocytes
}

\author{
Clara Redondo, ${ }^{\star}$ Ignacio Flores, ${ }^{\S}$ Ana Gonzalez, ${ }^{\S}$ Shigekazu Nagata, ${ }^{\ddagger}$ Ana C. Carrera, ${ }^{\S}$ Isabel Merida, ${ }^{\S}$ and Carlos Martinez-A ${ }^{\S}$ \\ *Hospital Ramon y Cajal, Madrid, Spain; ${ }^{\ddagger}$ Osaka Bioscience Institute, Suita, Osaka 565, Japan; and ${ }^{\S}$ Department of Immunology and \\ Oncology, Centro Nacional de Biotecnologia, CSIC, Universidad Autonoma, Campus de Cantoblanco, 28049 Madrid, Spain
}

\begin{abstract}
Fas is an apoptosis-signaling receptor molecule expressed in vivo on thymocytes, liver, heart, and ovary. In vivo administration of the anti-Fas Jo2 antibody in mice induces severe apoptotic liver damage leading to fulminant hepatitis and death. Linomide, a quinoline 3-carboxamide, inhibits apoptosis of $B$ and $T$ cells induced by various stimuli including viruses, superantigens, and glucocorticoids. Mice treated with linomide survived the lethal effect of anti-Fas antibody, did not accumulate ceramide in hepatocytes, and recovered liver structure and function within $96 \mathrm{~h}$ of anti-Fas injection, as confirmed by histology and glutamic oxalacetic transaminase, glutamic pyruvic transaminase, and lactate dehydrogenase levels. Surviving mice showed severe depletion of cortical thymocytes, but medullar thymic cells expressing high CD3 and Fas levels also survived the treatment with anti-Fas in the presence of linomide. Heart, lung, and ovary showed no signs of apoptosis promoted by Fas ligation. These results suggest that linomide prevents cell death triggered by Fas ligation and can be useful for therapeutic intervention in fulminant hepatitis. (J. Clin. Invest. 1996. 98:1245-1252.) Key words: apoptosis • ceramide • Fas - fulminant hepatitis • liver
\end{abstract}

\section{Introduction}

Apoptosis is believed to be the essential physiological process underlying control of programmed cell death during embryonic development, cell differentiation, or tissue turnover. Apoptosis is morphologically characterized by fragmentation of the cell together with the nucleus, resulting in the formation of apoptotic bodies which are subjected to phagocytosis $(1,2)$. The Fas molecule is one of the identified cell surface molecules which mediates external ligand-stimulated apoptosis $(3,4)$. There is presently little information on the signaling mechanisms that initiate the apoptotic response. Recently, however, the sphingomyelin pathway leading to ceramide production has been shown to participate in the early events in the apoptotic cascade of $\mathrm{TNF}-\alpha$, ionizing radiation, and Fas-induced programmed cell death (5).

Address correspondence to C. Martinez-A, Centro Nacional de Biotecnologia, Universidad Autonoma, Campus de Cantoblanco, 28049 Madrid, Spain. Phone: 34-1-585-4537; FAX: 34-1-372-0493; E-mail: cmartineza@samba.cnb.uam.es

Received for publication 13 February 1996 and accepted in revised form 27 June 1996.

J. Clin. Invest.

(C) The American Society for Clinical Investigation, Inc.

0021-9738/96/09/1245/08 \$2.00

Volume 98, Number 5, September 1996, 1245-1252
Linomide is an immunomodulator which has been found to inhibit apoptosis in vivo of peripheral $\mathrm{T}$ cells induced by various stimuli: Staphylococcus aureus enterotoxin B, glucocorticoids (GC), ${ }^{1}$ and vaccinia virus $(6,7)$. The activity implicated in prevention of apoptosis appears to be due to a metabolite, since linomide is devoid of any antiapoptotic activity in vitro (6). Linomide also reduces murine sensitivity for development of septic shock (8). These life-preserving effects of linomide may be related to partial inhibition of TNF production $(6,8)$, which is effective at the transcriptional level as demonstrated by semiquantitative PCR analysis. In contrast to cyclosporin A and GC, linomide exerts immunostimulatory effects in several systems and, in fact, antagonizes the immunosuppressive effects of cyclosporin A and GC in vivo $(9,10)$.

The Fas/Apo antigen (CD95) is a 45-kD single transmembrane receptor belonging to the family of the apoptosis-signaling molecules which is expressed on a variety of neoplasic and normal cells $(3,4,11,12)$, including those of thymus, heart, liver, and ovary. In lymphoid cells, Fas is preferentially expressed on the cell surface after cellular activation and plays a crucial role in the homeostasis of peripheral lymphocyte expansion, as well as in the apoptosis of autoreactive clones (1321). Cross-linking of Fas has been shown to activate an acidic sphingomyelinase and to promote an increase in ceramide concentration, suggested to be a mediator of apoptosis (5). Furthermore, T cell receptor cross-linking by antibodies or superantigens activates the Fas-Fas ligand (18-21) and promotes cell death which is inhibited by linomide (6). Therefore, we sought to identify the mechanism through which linomide prevents apoptosis in a model system based on the in vivo administration of an anti-Fas antibody which provokes animal death mediated by massive liver and thymocyte cell death. We show that linomide rescues mice from death, prevents cell death in liver as well as in medullar thymocytes, and prevents ceramide accumulation in hepatocytes. We also show that, in contrast to the case for the liver, Fas ligation does not trigger ceramide accumulation in thymocytes.

\section{Methods}

Mice and antibodies. BALB/c mice derived from Jackson mice were maintained and bred at the Centro Nacional de Biotecnologia (Madrid, Spain) animal facilities under pathogen-free conditions using cages and sterile workbenches. All experiments were carried out with $8-12$-wk-old age- and sex-matched mice. Mice received injections of the Jo2 antibody (22).

Phenotypic characterization. Thymuses were prepared by teasing the tissue through a nylon screen. Red cells were lysed by osmotic shock and single-cell suspensions prepared and stained with $\mathrm{mAb}$ against

1. Abbreviations used in this paper: DAG, diacylglycerol; GC, glucocorticoids; GOT, glutamic oxalacetic transaminase; GPT, glutamic pyruvic transaminase; $\mathrm{LDH}$, lactate dehydrogenase. 
CD3€ (145C11, Pharmingen, San Diego, CA), anti-CD4, anti-CD8, or Fas (Pharmingen), which were FITC- or PE-labeled as described (23).

Histological examination. Histological analyses of liver and thymus sections were prepared at different times after antibody injection and were hematoxylin and eosin stained.

Determination of ceramide levels. Appropriate liver and thymus fragments were suspended and homogenized in PBS at $4^{\circ} \mathrm{C}$. Lipids were extracted with chloroform/methanol/hydrochloric acid $(1 \mathrm{~N})$ (500:500:5, vol/ $\mathrm{vol}$ ) and centrifuged for $5 \mathrm{~min}$ at $500 \mathrm{~g}$. Lipids in the organic phase extract were then dried under $\mathrm{N}_{2}$ and thereafter sonicated in $10 \mathrm{mM}$ Tris, $\mathrm{pH}$ 7.4. Ceramide was quantified by the diacylglycerol (DAG) kinase as ${ }^{32} \mathrm{P}$ incorporated upon ceramide phosphorylation to ceramide-1-phosphate by DAG kinase (5). Purified Escherichia coli DAG kinase (Calbiochem-Novabiochem Corp., La Jolla, CA) in enzyme buffer ( $20 \mathrm{mM}$ Tris- $\mathrm{HCl}, 10 \mathrm{mM}$ dithiothreitol, $1.5 \mathrm{M} \mathrm{NaCl}, 250 \mathrm{mM}$ sucrose, and $15 \%$ glycerol, $\mathrm{pH} 7.4$ ) was added to the organic phase extract. [ $\left.\gamma^{-32} \mathrm{P}\right] \mathrm{ATP}(10 \mathrm{mM} ; 1,000 \mathrm{dpm} / \mathrm{pmol})$ in enzyme buffer was added to start the reaction. After $30 \mathrm{~min}$ at $22^{\circ} \mathrm{C}$, the reaction was terminated by extraction of lipids, as described above. The lower organic phase was dried under $\mathrm{N}_{2}$. Ceramide-1phosphate was resolved by TCL using $\mathrm{CHCl}_{3} / \mathrm{CH}_{3} \mathrm{OH} / \mathrm{HAc}$ (65:15:5, $\mathrm{vol} / \mathrm{vol}$ ) as solvent and detected by autoradiography. Lipids were separated by TCL and radioactive spots were visualized by autoradiography. Ceramide and DAG controls were included in the assay and quantitative results for ceramide-1-phosphate accumulation were obtained by autoradiograph scanning by comparison with a standard curve derived with $\mathrm{C} 2$-ceramide and analysis using an NIH Image Program (1.52).

\section{Results}

Protection from Fas-mediated death by linomide. Injection of antiFas antibody causes gross liver injury leading to hepatic failure

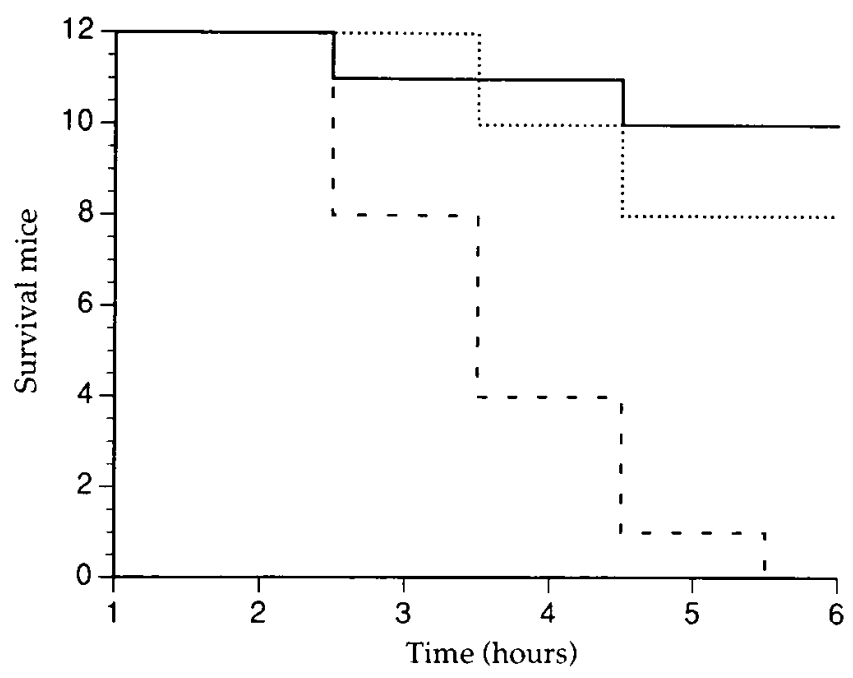

Figure 1. The effect of linomide administration on the mortality of mice inoculated with a lethal dose of anti-Fas antibody. Three different groups of 12-wk-old mice injected with $10 \mu \mathrm{g}$ of Jo2 antibody received different doses of linomide in drinking water or water alone. $2 \mathrm{~d}$ before intravenous injection of $10 \mu \mathrm{g}$ of Jo2 antibody, the mice received linomide in drinking water at a dose of either 100 (dotted line, $n=23$ ) or $300 \mathrm{mg} / \mathrm{kg} / \mathrm{d}$ (continuous line, $n=28$ ). Age-matched control mice (dashed line, $n=18$ ) received sterile water. Untreated mice and those treated with linomide were housed in adjacent cages in the same room, under sterile conditions. The data represent the survival curves of one experiment out of three performed. and death within $6 \mathrm{~h}$ and has been suggested as a model for human fulminant hepatitis (22). We explored the possible therapeutic use of linomide to prevent liver failure, as well as the effect of anti-Fas administration on other tissues such as thymus, heart, and ovary. Different concentrations of the Jo2 antibody were injected intravenously into BALB/c mice, which were either untreated or treated with one of two linomide doses $(100$ and $300 \mathrm{mg} / \mathrm{kg} / \mathrm{d}$ ) (Fig. 1). All untreated mice (18/18) receiving $10 \mu \mathrm{g}$ of Jo2 antibody died within $6 \mathrm{~h}$, but only $7 / 23$ mice treated with $100 \mathrm{mg} / \mathrm{kg} / \mathrm{d}$ and 4/23 mice treated with $300 \mathrm{mg} /$ $\mathrm{kg} / \mathrm{d}$ of linomide died. All mice treated with linomide alive $6 \mathrm{~h}$ after $\mathrm{Jo} 2$ antibody injection survived for the experimental period tested (at least $2 \mathrm{mo}$, when they were finally killed) with no sign of disease. Of the mice receiving $1 \mu \mathrm{g}$ of Jo2, only $1 / 6$ of the untreated mice but none $(0 / 6)$ of the linomide-treated group died (not shown). These results confirm the lethal effect of the Jo2 antibody (22) and show that intravenous injection required lower doses than intraperitoneal administration to induce the same lethal effect. More importantly, we show that linomide prevented the lethal effect of the anti-Fas antibody in a dose-dependent manner.

Biochemical analysis of the mouse sera confirmed previous findings (22) of dramatic increases in the levels of liver specific enzymes, glutamic pyruvic transaminase (GPT), and glutamic oxalacetic transaminase (GOT) in serum before death (Table I). Also of interest is the 30 -fold increase in lactate dehydrogenase (LDH), representative of release from intracellular stores due to intensive cell death. Alkaline phosphatase, amylase, $\mathrm{Na}^{+}$, and $\mathrm{K}^{+}$increased only marginally (not shown). Linomide prevented, in a dose-dependent fashion, the sustained increase of GPT, GOT, and LDH promoted by anti-Fas. Thus, as shown in Table I, GPT, GOT, and LDH levels decreased to normal values $72 \mathrm{~h}$ after anti-Fas administration. Treating the mice

Table I. Biochemical Analysis of the Serum of Mice Receiving Anti-Fas Antibody Injections and Treated with Linomide

\begin{tabular}{rcccc}
\hline Time & Linomide & GPT & GOT & LDH \\
\hline$(h)$ & $(m g / k g / d)$ & $\left(I U 1^{-1}\right)$ & $\left(I U 1^{-1}\right)$ & $\left(I U 1^{-1}\right)$ \\
0 & 0 & $53 \pm 12$ & $109 \pm 31$ & $1100 \pm 250$ \\
1 & 0 & $295 \pm 65$ & $607 \pm 190$ & $2600 \pm 590$ \\
1 & 100 & $106 \pm 28$ & $250 \pm 72$ & $1200 \pm 310$ \\
1 & 300 & $72 \pm 22$ & $122 \pm 39$ & $1030 \pm 210$ \\
3 & 0 & $16300 \pm 2500$ & $16100 \pm 3100$ & $37600 \pm 5100$ \\
3 & 100 & $15600 \pm 1800$ & $12700 \pm 2200$ & $32200 \pm 4300$ \\
3 & 300 & $5600 \pm 1500$ & $5200 \pm 1100$ & $10400 \pm 1700$ \\
24 & 300 & $760 \pm 210$ & $540 \pm 180$ & $\mathrm{ND}$ \\
48 & 300 & $160 \pm 42$ & $210 \pm 63$ & $\mathrm{ND}$ \\
72 & 100 & $106 \pm 25$ & $140 \pm 31$ & $1040 \pm 180$ \\
72 & 300 & $80 \pm 17$ & $140 \pm 25$ & $980 \pm 150$
\end{tabular}

Purified (10 $\mu \mathrm{g} /$ mouse) anti-Fas antibody (Jo2) in $200 \mu \mathrm{l}$ of PBS was injected intravenously into 12-wk-old BALB/c mice which had been administered different linomide concentrations (100 or $300 \mathrm{mg} / \mathrm{kg} / \mathrm{d}$ ) in drinking water for $48 \mathrm{~h}$. At the times indicated, blood samples were collected and various biochemical parameters quantified using a standard automatic clinical analyzer. The results show the values obtained in one experiment out of three performed, and represent the mean and standard deviation obtained using four mice/group. IUl, international units/liter. 
with linomide concentrations below $100 \mathrm{mg} / \mathrm{kg} / \mathrm{d}$ had no effect on survival. Concentrations above $300 \mathrm{mg} / \mathrm{kg} / \mathrm{d}$ are difficult to achieve by oral administration, since mice drink less or refused water due to the change in taste, and the systemic levels of linomide are consequently more difficult to control. We conclude that linomide prevents, in a dose-dependent manner, the progressive liver damage induced by anti-Fas antibody, and that these results indicate that the mice quickly and fully recover the biochemical profile and hepatic structure if appropriate treatment is given.

Linomide prevents liver and thymus destruction. Tissue sections from all the mouse organs were examined histologically at intervals ranging from $50 \mathrm{~min}$ to $96 \mathrm{~h}$ after intravenous injection. The injection of 0.1 and $1.0 \mu \mathrm{g}$ of anti-Fas antibody did
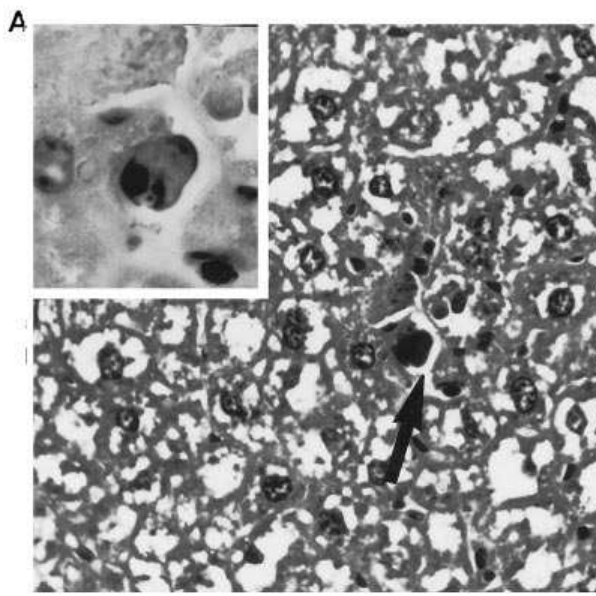

C

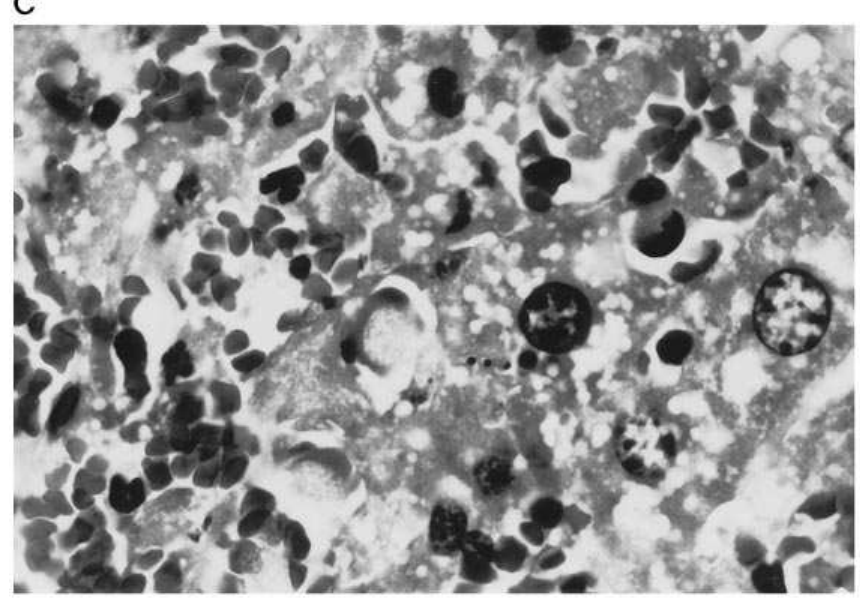

E

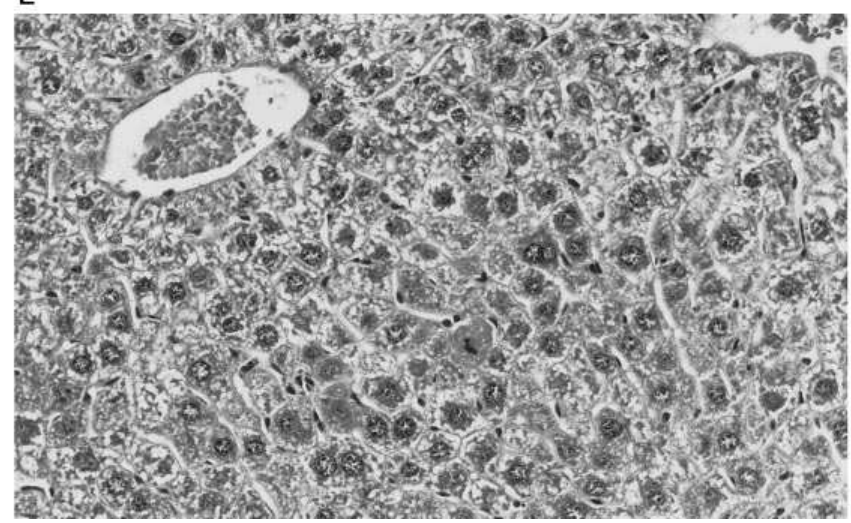

B

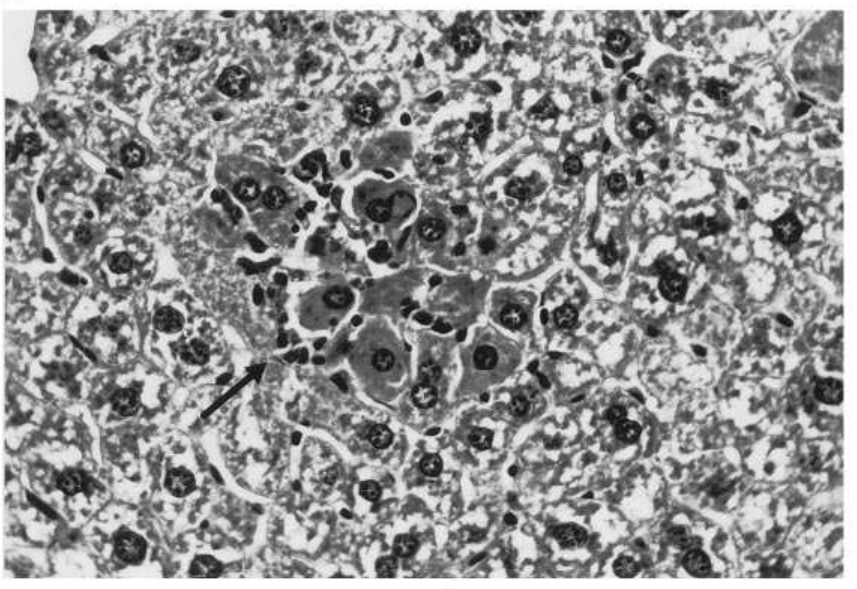

$\mathrm{D}$

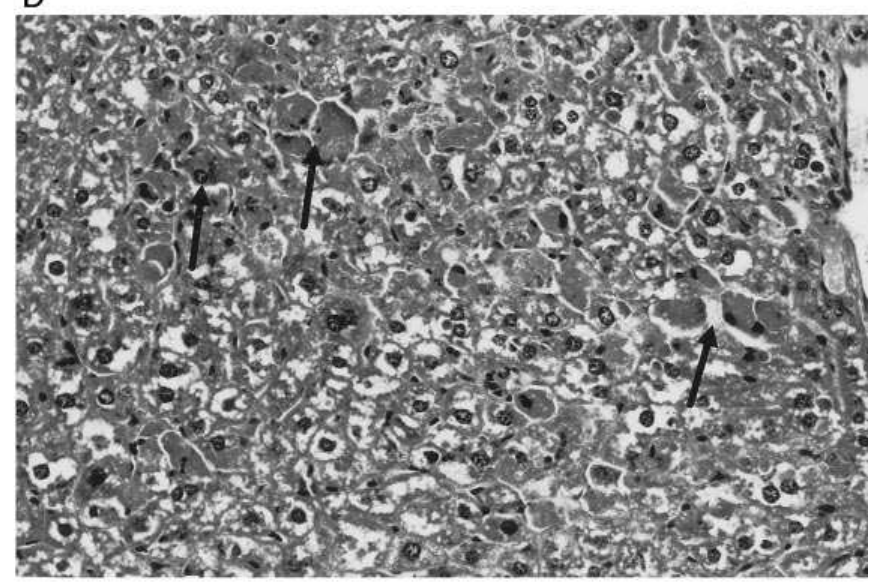

$\mathrm{F}$

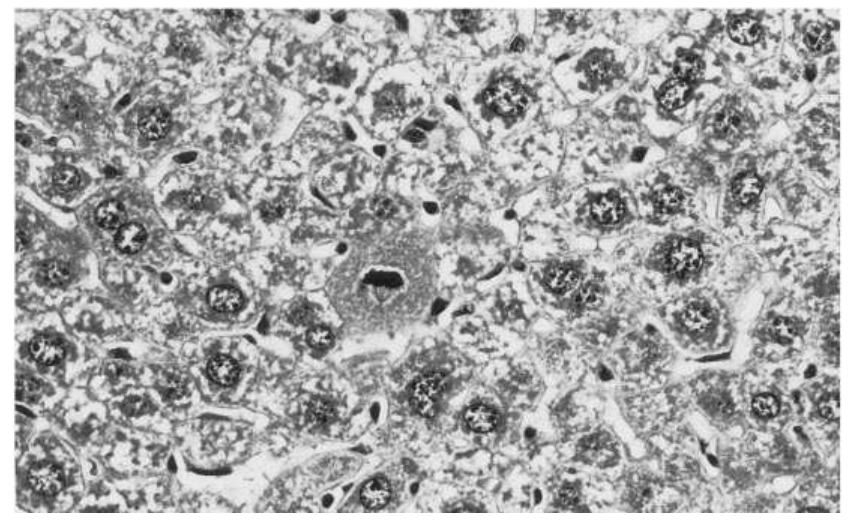

Figure 2. Liver sections of mice injected with $10 \mu \mathrm{g}$ of Jo2 with no treatment ( $A$ and $C$ ) or receiving $300 \mathrm{mg} / \mathrm{kg} / \mathrm{d}$ of linomide $(B, D, E$, and $F)$. $A$ and $B$ show $40 \mathrm{~min}$ after injection (the inset in $A$ and the arrow in $A$ and $B$ indicate a focus of apoptotic cells), while $C$ shows a diffuse hemorrhage and massive apoptotic death of hepatocytes and $D$ shows only multiple foci of apoptotic cells (indicated by arrows). $E$ and $F$ are $4 \mathrm{~d}$ after treatment, showing a lack of apoptosis and a regenerative pattern of liver cells. $A, \times 100$, inset $\times 1,000 ; B$ and $C, \times 400 ; D$ and $E, \times 200 ; F, \times 400$. 
not produce hepatic lesions. Animals receiving $10 \mu \mathrm{g}$ of $\mathrm{Jo} 2$ which were not linomide treated (Fig. $2 A$ ) and those treated with $100 \mathrm{mg} / \mathrm{kg} / \mathrm{d}$ of linomide showed scattered hepatic foci of apoptotic cells $50 \mathrm{~min}$ after injection. Mice receiving $300 \mathrm{mg} /$ $\mathrm{kg} / \mathrm{d}$ of linomide produced either spotty or no hepatic apoptosis (Fig. 2 B). A dramatic picture appeared 2-3 h after injection. Untreated animals showed grossly evident diffuse hemorrhage with massive and diffuse hepatocyte apoptosis, where virtually no live hepatocytes are detected (Fig. 2 C). When the hepatocytes were quantitated under high-power magnification, $>90 \%$ were undergoing apoptosis. However, animals receiving 100 or $300 \mathrm{mg} / \mathrm{kg} / \mathrm{d}$ of linomide showed less apoptosis and little or no hemorrhage (Fig. $2 D$ ). In contrast to untreated mice, when mice received linomide, the frequency of hepatocytes undergoing apoptosis was $<50 \%$. After $48 \mathrm{~h}$, the livers of surviving animals (all receiving linomide) had fully recovered their normal structure. A high mitotic index (4-5/HPF) and a "regenerative pattern" of liver cells were the only signs
A

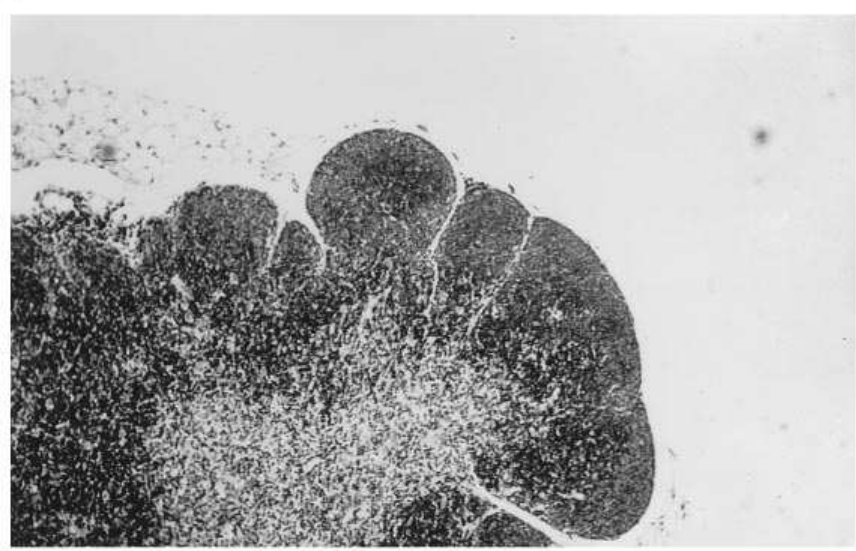

C

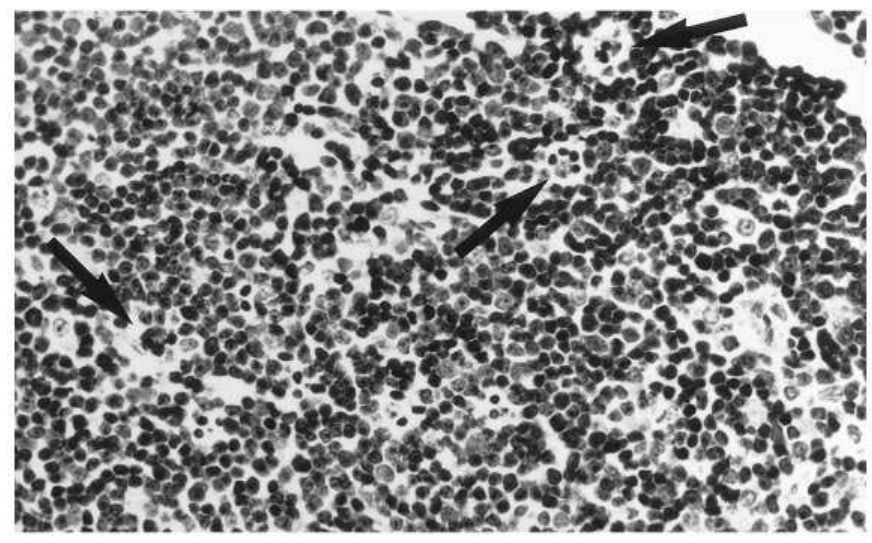

$E$

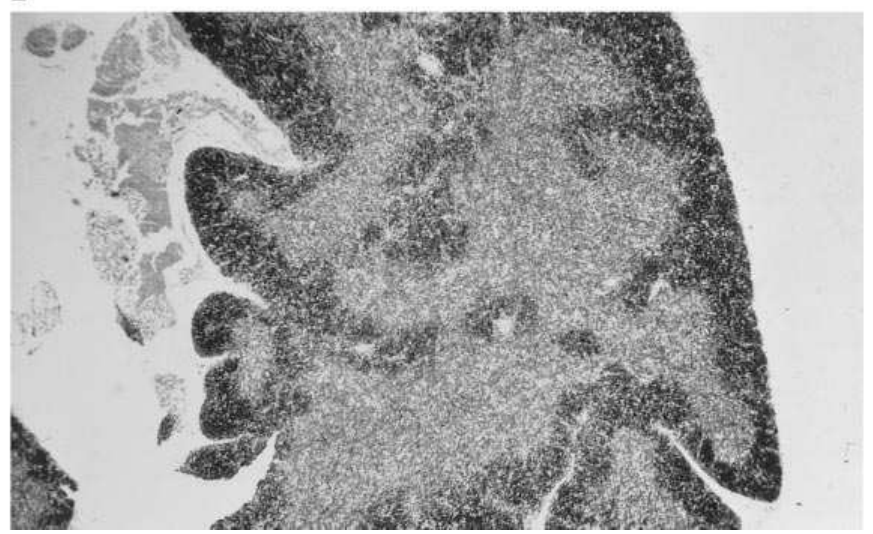

B

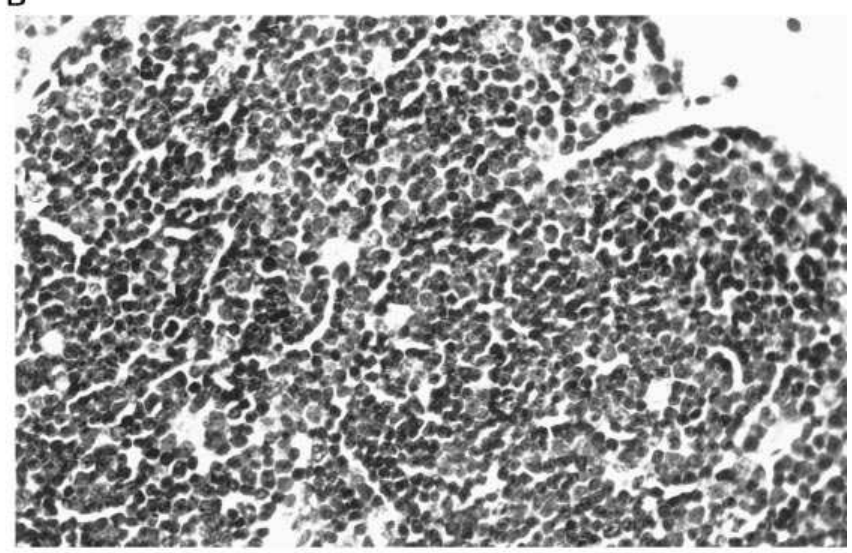

D

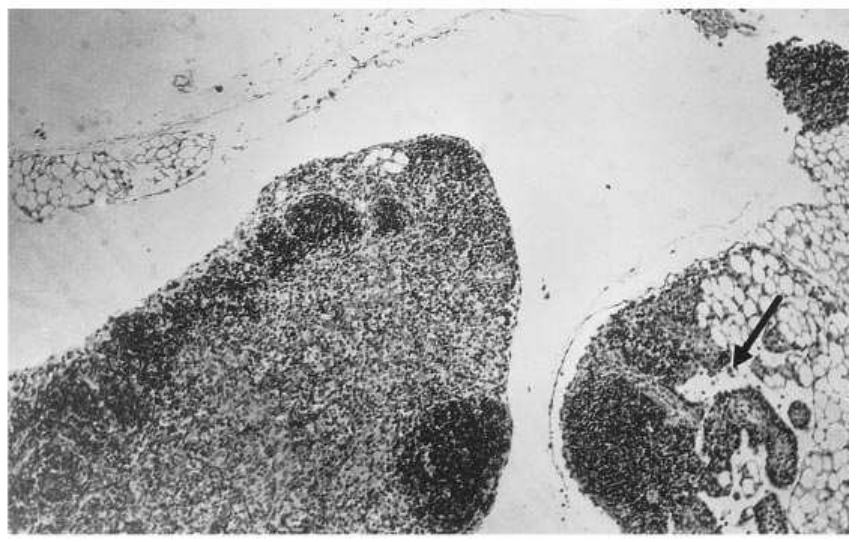

$\mathrm{F}$

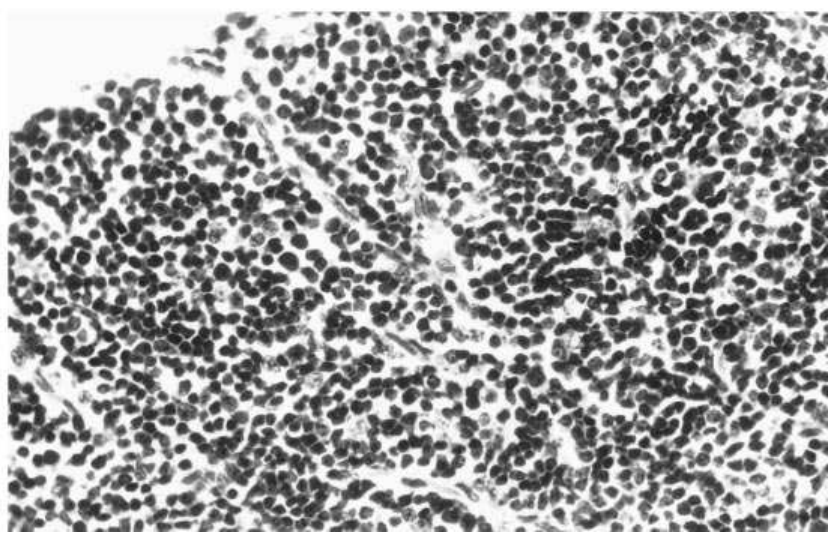

Figure 3. Thymus sections from mice receiving linomide (300 mg/kg/d) $(A$ and $B)$; injected 50 or 360 min earlier with $10 \mu \mathrm{g}$ of Jo2 antibody $(C$ and $D$, respectively); or injected $4 \mathrm{~d}$ earlier with $10 \mu \mathrm{g} /$ mouse Jo2 antibody and receiving $300 \mathrm{mg} / \mathrm{kg} / \mathrm{d}$ linomide $(E$ and $F)$. The arrow in $C$ indicates pyknosis and phagocytosis with a starry-sky pattern, and in $D$, an organoid pattern of epithelial cells. $A, D$, and $E, \times 40 ; B, C$, and $F, \times 400$. 
of a previous lesion. $4 \mathrm{~d}$ later, the liver cells still showed regenerative characteristics, but the mitotic index was lower (1-2/ HPF) (Fig. $2 E$ ) and more clearly visualized, as shown under high-power magnification in Fig. $2 F$.

Histological analysis was also performed on the thymus. When compared with that of untreated mice (Fig. 3, $A$ and $B$ ), the thymus showed morphological changes only after injection of $10 \mu \mathrm{g}$ of Jo2. $50 \mathrm{~min}$ after injection, pyknosis and phagocytosis of cortical thymocytes displaying a classical starry-sky pattern appeared (Fig. $3 C$ ) and $3 \mathrm{~h}$ later, an involutive tendency was evident, with clear medullary widening and cortical thinning (Fig. $3 \mathrm{D}$ ). $4 \mathrm{~d}$ later, the surviving animals which had been treated with 100 or $300 \mathrm{mg} / \mathrm{kg} / \mathrm{d}$ of linomide showed less marked or no atrophy (Fig. $3 E$ ), less prominent pyknosis and phagocytosis, and absence of the prominent starry-sky pattern (Fig. $3 F$ ). The lung, heart, gastrointestinal tract, kidney, and pancreas showed no pathological changes at any time or linomide dose. Findings in the ovary were not consistent, probably due to the fact that animals had not been selected on the basis of the sexual cycle.

As shown above, anti-Fas antibody injection obliterated mostly cortical thymocytes. The surviving thymic cell population in linomide-treated mice, based on histopathological findings, showed massive cell death $24 \mathrm{~h}$ after anti-Fas injection $\left(120 \times 10^{6}\right.$ thymocytes in untreated mice vs. $34 \times 10^{6}$ thymocytes in linomide-treated mice), which continued $96 \mathrm{~h}$ after injection. Most surprising was the clear shift in Fas expression $72 \mathrm{~h}$ after anti-Fas injection (Fig. $4 A$ ). The thymic population which expressed intermediate levels of Fas (double-positive thymocytes) died, while cells expressing either high or low Fas

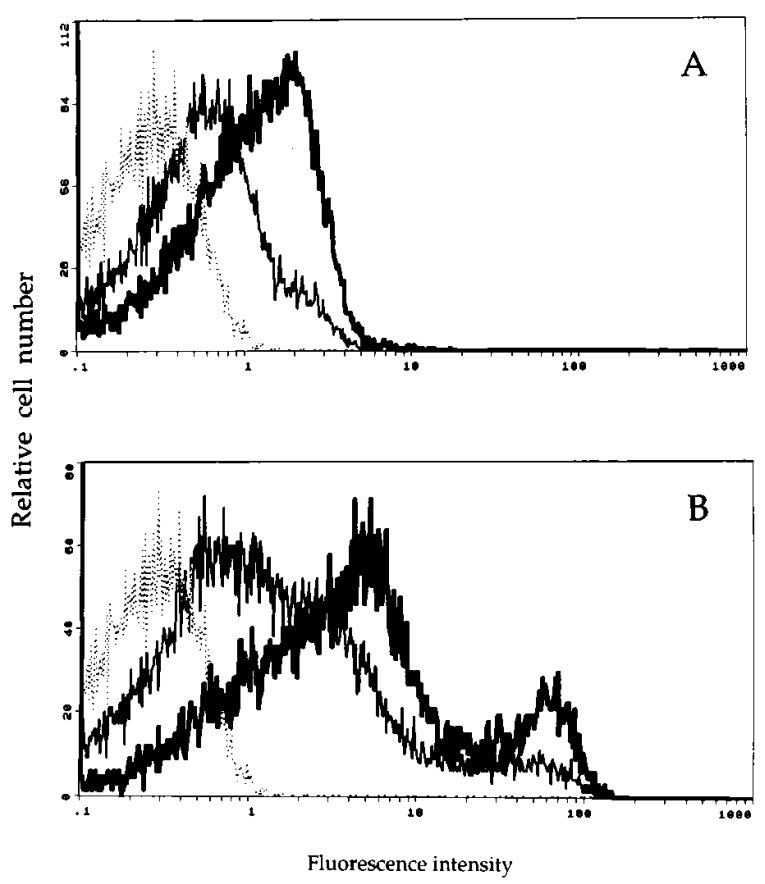

Figure 4. Expression of Fas and TCR-CD3 by thymocytes before (solid line) and after injection with Jo2 antibody (dark line) into linomide-treated mice $(300 \mathrm{mg} / \mathrm{kg} / \mathrm{d})$. Expression was tested by FACS ${ }^{\circledR}$ analysis $72 \mathrm{~h}$ after in vivo intravenous injection using anti-Fas antibody $(A)$ or anti-CD3 antibody $(B)$, followed by FITC-labeled anti-hamster antibody. Reactivity of an irrelevant, isotype-matched antibody is represented by the dotted line. levels survived. Fas or CD3 expression levels are not modified by linomide treatment as detected in cytofluorometric analysis using FITC-labeled anti-CD3 antibodies. In fact, the mean fluorescence intensity for Fas expression is 58.6 and 60.3 for untreated and linomide-treated mice, respectively, which in the case of CD3 expression is 48.5 and 49.2 in untreated and linomide-treated mice, respectively (here considering the bright $\mathrm{CD}^{+}$cells). As shown in Fig. $4 \mathrm{~B}$, selective depletion of double-positive $\left(\mathrm{CD}^{+} \mathrm{CD}^{+}\right)$thymocytes resulted in the preferential survival of mature, bright CD3 thymocytes. Thus, double staining with anti-CD4 and anti-CD8 antibodies reveals that from $82 \%, \mathrm{CD}^{+} \mathrm{CD}^{+}$double-positive thymocytes decreased to almost background levels $48 \mathrm{~h}$ after anti-Fas administration. The selective decrease in $\mathrm{CD} 4^{+} \mathrm{CD} 8^{+}$thymocytes is associated with an increase in $\mathrm{CD} 4^{-} \mathrm{CD} 8^{-} \mathrm{T}$ cell precursor frequencies as well, as in $\mathrm{CD}^{+} \mathrm{CD} 4^{+} \mathrm{CD} 8^{-}$and $\mathrm{CD}^{+}{ }^{+} \mathrm{CD} 4^{-} \mathrm{CD} 8^{+}$ mature $\mathrm{T}$ cells (Fig. 5). The enrichment of mature thymocytes after Jo2 injection correlated with enhanced proliferative responses obtained in vitro after anti-CD3 stimulation. Thymocytes from mice injected with $10 \mu \mathrm{g}$ of Jo2 antibody and receiving $300 \mathrm{mg} / \mathrm{kg} / \mathrm{d}$ of linomide, when stimulated in vitro in microtiter plates coated with anti-CD3€ antibodies, showed a twofold increase in proliferation compared with thymocytes from untreated mice, as measured by $\left[{ }^{3} \mathrm{H}\right]$ thymidine uptake (not shown) (21). These results show that mature $\mathrm{CD}^{+} \mathrm{CD}^{-} /$ $\mathrm{CD}^{-}$thymocytes are resistant to cell death induced by antiFas antibodies in the presence of linomide, while linomide does not prevent the cell death of immature $\mathrm{CD}^{+} \mathrm{CD}^{+}$cortical thymocytes.

Linomide prevents accumulation of ceramide. Fas binding by antibodies activates sphingomyelinase and generates ceramide (5). Moreover, Fas-sensitive cell lines tested could be induced to apoptosis after exposure to cell-permeable C2-cera-
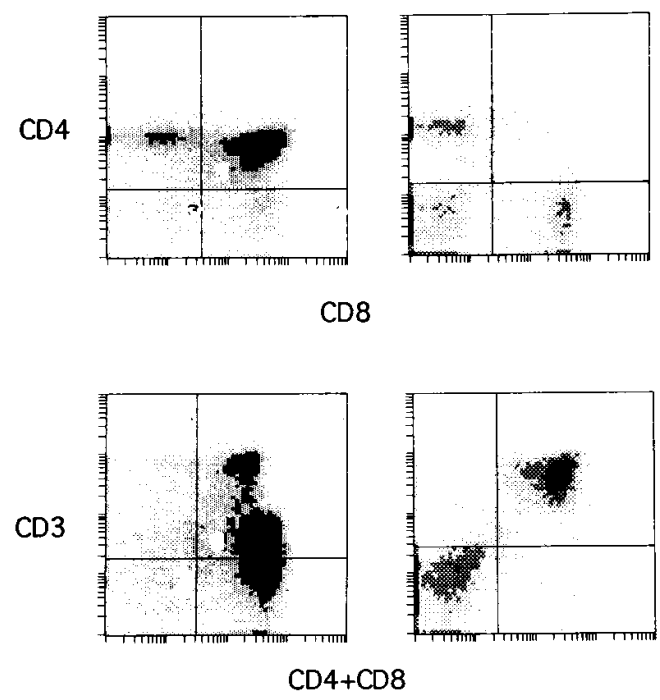

Figure 5. The anti-Fas antibody kills off immature $\mathrm{CD} 4^{+} \mathrm{CD} 8^{+}$thymocytes. $\mathrm{BALB} / \mathrm{c}$ mice receiving linomide in drinking water were injected with anti-Fas antibody Jo2 or left untreated. After $48 \mathrm{~h}$, surviving mice were tested for $\mathrm{CD} 4, \mathrm{CD} 8$, and $\mathrm{CD} 3$ expression using FITC-labeled anti-CD4 and PE-labeled anti-CD8 antibodies or PElabeled anti-CD4 and anti-CD8 and FITC-labeled anti-CD3 antibodies. The figure shows the staining obtained with thymocytes from mice treated with linomide alone (left) or mice also receiving anti-Fas antibody (right). 


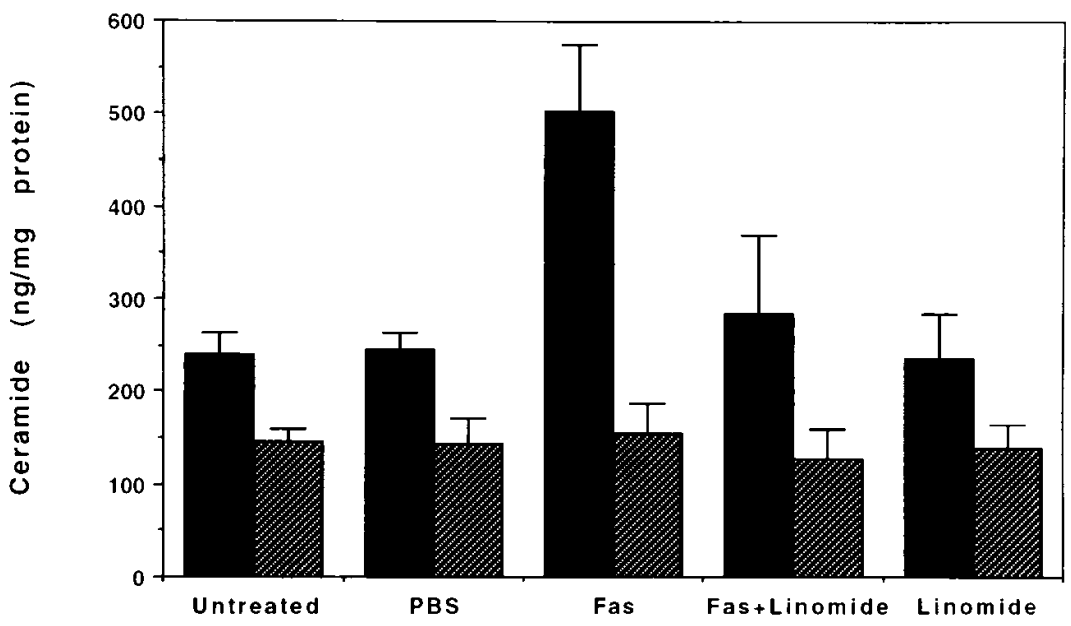

Figure 6. Ceramide accumulation after anti-Fas injection. Mice given linomide or untreated were intravenously injected with $15 \mu \mathrm{g} /$ mouse of Jo2 antibody. 15 min after Jo2 injection, mice were killed, their livers (filled bars) and thymuses (hatched bars) collected, and lipids extracted and assayed with E. coli DAG kinase. Lipids were separated by TCL and radioactive spots were visualized by autoradiography. Ceramide and DAG controls were included in the assay and quantitative results for ceramide-1-phosphate accumulation were obtained by scanning the autoradiograph and analyzing the results using the NIH Image Program 1.52, as described in Methods. The figure shows the mean and the standard error of the means obtained in three different experiments. mide, indicating that ceramide may be an intracellular messenger leading to apoptotic cell death (24). The production of ceramide by anti-Fas treatment has only been tested previously in hematopoietic cells (25), so we tested hepatocyte and thymus ceramide production. Mice received intravenous injections of progressively increasing concentrations of $\mathrm{Jo} 2$ antibody (0.2-20 $\mu \mathrm{g} / \mathrm{mouse})$ and the liver was analyzed from 5 to 50 min later. Ceramide production was measured as described by the DAG kinase assay (5) and the results are shown in Fig. 5. Mice injected with anti-Fas antibody, both linomide-treated as well as untreated, showed an increase in ceramide levels in liver, which lasts for $5 \mathrm{~min}$, and also occurs in PBS-injected mice. We believe this is a consequence of stress produced by manipulation (not shown). More relevant is that, in mice receiving anti-Fas antibody, ceramide levels increased for up to $15 \mathrm{~min}$, decreasing thereafter, while in the presence of linomide, ceramide levels decreased to those found in untreated mice (Fig. 6). Of interest, when thymus samples were analyzed for ceramide, we found that the anti-Fas antibody, in contrast to the case for liver, does not trigger an increase in ceramide levels (Fig. 6). We conclude that linomide prevents the apoptotic death of hepatocytes as well as the accumulation of ceramide after Fas ligation. Furthermore, although some hepatocytes die, as shown by increased GPT, GOT, and LDH levels, this destruction is self-limited and transient in the present of linomide; the liver regenerates morphologically and functionally within $72 \mathrm{~h}$, for the remainder of the animal's life.

\section{Discussion}

Apoptosis appears to be an important regulator of immune response and inflammation during viral and bacterial infection (1). Growing evidence is being presented that apoptosis is closely controlled by various gene products which promote cell death. Among them, the Fas antigen, abundantly expressed in the thymus, liver, heart, lung, kidney, and ovary, has being identified recently as the putative surface molecule capable of transducing apoptotic signals into cells (26). A cytotoxic antibody against mouse Fas has been shown to kill wild-type mice by inducing massive liver destruction (22).

The liver plays a central and varied role in many essential physiologic processes, and liver failure constitutes the final outcome of many diseases ranging from metabolic, viral, parasitic, bacterial, and fungal infections, to drug-induced and sus- tained inflammatory processes. These processes, independent of the triggering mechanisms, involve hepatic apoptosis which, when uncontrolled, threatens the individual's life by fulminant hepatitis. A number of experimental animal models are currently available to screen and test new pharmacological compounds designed to curtail massive hepatic apoptosis. Recently, abnormal activation of the Fas-Fas ligand interaction was shown to play a role in cell death, including hepatocyte death (13-21). Consequently, transgenic mice carrying the human hepatitis virus $\mathrm{B}$ on an albumin promoter and injected with CTLs specific for the HBV antigen and mice injected with anti-Fas antibodies appear to represent good models for human fulminant hepatitis $(27,28)$.

Liver destruction also occurs when several polyclonal stimulators, such as bacterial lipopolysaccharide (29), bacterial enterotoxins (i.e., Staphylococcus aureus B) (30), or anti-CD3€ antibodies (31), are administered in vivo. They induce a series of toxic effects denominated septic shock, which includes hyperthermia, hypothermia, bradycardia, cardiovascular and liver destruction, leading to death (32). The pathology of septic shock is mediated by the interplay between various cytokines, among which TNF plays a critical role $(32,33)$. Accordingly, passive immunization against TNF improved survival in different animal models of LPS-mediated septic shock (34). Using four distinct models, we have shown previously that linomide prevents septic shock in mice $(6,8)$ and that it partially blocks TNF production (up to $60 \%$ ), both in vivo and ex vivo $(6,8)$. We have now carried the analysis one step further and have shown that, in hepatocytes, linomide also prevents accumulation of ceramide induced by Fas ligation. Therefore, it appears that the protective role of linomide in septic shock survival is mediated by the two actions, inhibition of TNF production and ceramide accumulation, in hepatocytes. Our results show that linomide not only prevents septic shock (in which experimental animals die of liver failure), but also liver destruction triggered by other means, and therefore, linomide may be a good candidate for the treatment of fulminant hepatitis.

It appears that ceramide may act as a physiological mediator of cell death (35-37). In fact, ceramide transduces the effects of TNF- $\alpha$ (locally produced after hepatitis B viral infection) (38), as well as Fas ligation and perhaps other extracellular agents, on cell death. It has not escaped our attention that the prevention of ceramide accumulation by linomide suggests additional uses for linomide in degenerative diseases associ- 
ated with cell death. Experiments are currently underway to test this possibility. Thus, apoptosis mediated by Fas may have a broader implication for the immune response and autoimmune disease in general. For example, apoptosis has been observed in freshly isolated T cells from HIV-infected individuals, but not from uninfected individuals (39). Thus, apoptosis may play a role in the diminution of $\mathrm{CD}^{+} \mathrm{T}$ cells and the progression to AIDS in HIV-infected individuals. If so, therapeutic intervention for HIV-infected individuals with a Fas antagonist may be possible and linomide may become a useful target for pharmacological intervention.

In this manuscript, we also show that linomide acts by reducing Fas-induced apoptosis. In contrast, after Fas and linomide treatment, thymocytes retain this striking Fas-related selection. Indeed, only mature thymocytes survive Fas-mediated killing. The inability of linomide to promote double-positive thymocyte survival correlates with previous results showing its inability to prevent in vivo glucocorticoid-induced programmed cell death in thymocytes, while being effective in splenocytes (6). The differential susceptibility of thymus and peripheral $\mathrm{T}$ cells to linomide might reflect the existence of more than one pathway in the induction of apoptosis. In fact, it is well illustrated that Fas-Fas ligand interaction actively participates in the homeostasis of spleen $\mathrm{T}$ cells, while it has no role in the thymus (40).

Our results showing that Fas ligation does not trigger accumulation of ceramide in the thymus are therefore relevant in two contexts. First, they support the view that prevention of apoptosis and inhibition of ceramide accumulation might be linked. Second, the pathway through which Fas ligation triggers apoptosis may not be the same in different cell lineages and therefore, additional effector molecules specific for apoptosis in thymocytes might be activated. Finally, these data indicate that linomide might have some other function besides preventing apoptosis, since ceramide production, also associated with cytokine responses, does not always trigger apoptosis.

\section{Acknowledgments}

We thank Drs. M.A.R. Marcos, E. Montoya, and J. Rodes for critical reading of the manuscript; E. Leonardo, C. Bastos, and C. Moreno for technical and secretarial assistance and help with the FACS ${ }^{\circledR}$, respectively, and L. Gomez for help with the mice.

This study was supported in part by grants from the Comision Interministerial de Ciencia y Tecnologia (CICyT), Comunidad de Madrid (CAM). The Department of Immunology and Oncology was founded and is supported by Pharmacia and the CSIC

\section{References} 363.

1. Möller, G., editor. 1994. Apoptosis in immunity. Immunol. Rev. 142:9-

2. Cohen, J.J., R.R. Duke, V.A. Fadok, and K.S. Selling. 1992. Apoptosis and programmed cell death in immunity. Ann. Rev. Immunol. 10:267-293.

3. Itoh, N., S. Yonehara, A. Ishii, M. Yonehara, S.-I. Mizushimi, M. Sameshimi, A. Hase, Y. Seto, and S. Nagata. 1991. The polypeptide encoded by the cDNA for human cell surface antigen Fas can mediate apoptosis. Cell. 66: $233-240$.

4. Oehm, A., I. Behrmann, W. Falk, M. Pawlita, G. Maier, C. Klas, M. LiWeber, S. Richards, J. Dhein, and B.C. Trauth. 1992. Purification and molecular cloning of the APO-1 cell surface antigen, a member of the tumor necrosis factor/nerve growth factor receptor superfamily. J. Biol. Chem. 267:1070910715 .

5. Cifone, M.G., R. de Maria, P. Rocaioli, M.R. Rippo, M. Azuma, and L. Lanier. 1993. Apoptotic signaling through CD95 (Fas/Apo-1) activates an acidic sphingomyelinase. J. Exp. Med. 177:1547-1552.
6. Gonzalo, J.A., A.G. García, T. Kalland, G. Hedlund, C. Martínez-A, and G. Kroemer. 1994. Linomide inhibits programmed cell death of peripheral $\mathrm{T}$ cells in vivo. Eur. J. Immunol. 24:48-52.

7. Baixeras, E., L. Bosca, C. Stauber, A. González, A.C. Carrera, J.A. Gonzalo, and C. Martínez-A. 1994. From apoptosis to autoimmunity. Insights from signaling pathways leading to proliferation or to programmed cell death Immunol. Rev. 142:53-91.

8. Gonzalo, J.A., A. Gonzalez-Garcia, T. Kalland, G. Hedlund, C. Martinez-A, and G. Kroemer. 1994. Linomide, a novel immunomodulator that prevents death in four models of septic shock. Eur. J. Immunol. 23:2372-2378.

9. Wanders, A., and G. Tufveson. 1989. Abolition of the effect of cyclosporin A on rat cardiac allograft rejection by the new immunomodulator LS 2616 (Linomide). Transplantation (Baltimore). 47:216-221.

10. Stålhandske, T., and T. Kalland. 1986. Effects of the novel immunomodulator LS2616 on the delayed type hypersensitivity reaction to Bordetella pertussis in the rat. Immunopharmacology. 11:87-92.

11. Smith, C.A., T. Farrah, and R.G. Goodwin. 1994. The TNF receptor superfamily of cellular and viral proteins: activation, costimulation and death Cell. 76:959-962.

12. Watanabe-Fukunaga, R., C.L. Brannan, N. Itoh, S. Yonehara, N.G. Copeland, N.A. Jenkins, and S. Nagata. 1992. The cDNA structure, expression, and chromosomal assignment of the mouse Fas antigen. J. Immunol. 148:1274-1279.

13. Suda, T., and S. Nagata. 1994. Purification and characterization of the Fas-ligand that induces apoptosis. J. Exp. Med. 179:873-879.

14. Ju, S.-T., H. Cui, D.J. Panka, R. Ettinger, and A. Marshak-Rothstein. 1994. Participation of target Fas protein in apoptosis pathway induced by CD ${ }^{+}$ Th1 and CD8 ${ }^{+}$cytotoxic T cells. Proc. Natl. Acad. Sci. USA. 91:4185-4189.

15. Watanabe-Fukunaga, R., C.L. Brannan, N.G. Copeland, N.A. Jenkins, and S. Nagata. 1992. Lymphoproliferation disorder in mice explained by defects in Fas antigen that mediates apoptosis. Nature (Lond.). 356:314-317.

16. Vignaux, F., and P. Golstein. 1994. Fas-based lymphocyte-mediated cytotoxicity against syngeneic activated lymphocytes: a regulatory pathway? Eur. J. Immunol. 24:923-927.

17. Cheng, J., T. Zhou, C. Liu, J.P. Shapiro, M.J. Brauer, M.C. Kiefer, P.J. Barr, and J.D. Mountz. 1994. Protection from Fas mediated apoptosis by a soluble form of the fas molecule. Science (Wash. DC). 263:1759-1762.

18. Dhein, J., H. Walczak, C. Baumier, K.-M. Debatin, and P.H. Krammer. 1995. Autocrine T-cell suicide mediated by APO-1 (Fas/CD95). Nature (Lond.). 373:438-440.

19. Brunner, T., R.J. Mogil, D. LaFace, N.J. Yoo, A. Mahboubl, F. Echeverri, S.J. Martin, W.R. Force, D.H. Lynch, and C.F. Ware. 1995. Cell-autonomous Fas (CD95)/Fas-ligand interaction mediates activation-induced apoptosis in T-cell hybridomas. Nature (Lond.). 373:441-443.

20. Ju, S.-T., D.J. Panka, H. Cui, R. Ettinger, M. El-Khatib, D.H. Sherr, B.Z. Stanger, and A. Marshak-Rothstein. 1995. Fas (CD95)/Fas L interactions required for programmed cell death after T-cell activation. Nature (Lond.). 373: 444-448.

21. Vignaux, F., E. Vivier, B. Malissen, V. Depraeture, S. Nagata, and P. Goldstein. 1995. TCR/CD3 coupling to Fas-based cytotoxicity. J. Exp. Med. 181:781-786.

22. Ogasawara, J., R. Watanabe-Fukunaga, M. Adachi, A. Matsuzawa, T. Kasugai, Y. Kitamura, N. Itoh, T. Suda, and S. Nagata. 1993. Lethal effect of the anti-Fas antibody in mice. Nature (Lond.). 364:806-809.

23. Andreu, J.L., I. Moreno de Alboran, M.A.R. Marcos, A. Sanchez, C. Martinez-A, and G. Kroemer. 1991. IL2 promotes the autoaggressive function of cell expressing a forbidden TEC repertoire. Induction of autoimmunity in neonatally thymectomized CBA/H mice. J. Exp. Med. 173:1323.

24. Obeid, L.M., C.M. Linardic, L.A. Karolak, and Y.A. Hannun. 1993. Programmed cell death induced by ceramide. Science (Wash. DC). 259:17691771.

25. Gulbins, E., R. Bissonette, A. Mahboubi, S. Martin, W. Nishioka, T. Brunner, G. Baier, G. Baier-Bitterlich, C. Byrd, F. Lang, et al. 1995. Fasinduced apoptosis is mediated via a ceramide-initiated ras signaling pathway. Immunity. 2:341-351.

26. Nagata, S., and T. Suda. 1995. Fas and Fas ligand: lpr and gld mutations. Immunol. Today. 16:39-42.

27. Moriyama, T., S. Guilhot, K. Klopchin, B. Moss, C.A. Pinkert, R.D. Palmiter, R.L. Brinster, O. Kanagawa, and F.V. Chisari. 1990. Immunobiology and pathogenesis of hepatocellular injury in hepatitis B virus transgenic mice. Science (Wash. DC). 248:361-364.

28. Chirari, F.V. 1992. Hepatitis B virus biology and pathogenesis. Mol. Genet. Med. 2:67-72.

29. Lehmann, V., M.A. Freudenberg, and C. Galanos. 1987. Lethal toxicity of lipopolysaccharide and tumor necrosis factor in normal and D-galactosamine-treated mice. J. Exp. Med. 165:657-664.

30. Miethke, T., C. Wahl, K. Heeg, B. Echtenacher, P.H. Krammer, and H. Wagner. 1992. T cell-mediated lethal shock triggered in mice by the superantigen staphylococcal enterotoxin B: critical role of tumor necrosis factor. J. Exp. Med. 175:91-98.

31. Alegre, M.L., P. Vandenabeele, M. Depierreux, S. Florquin, M. DeschodtLanckman, V. Flamand, N. Moserm, O. Leo, J. Urbain, W. Fiers, and M. Goldman. 1991. Cytokine release syndrome induced by the 145-2C11 anti-CD3 mono- 
clonal antibody in mice: prevention by high doses of methylprednisolone. J. Immunol. 146:1184-1191.

32. Vassalli, P. 1992. The lethal toxicity of lipopolysaccharide and tumor necrosis factor in normal and D-galactosamine-treated mice pathophysiology of tumour necrosis factor. Ann. Rev. Immunol. 10:411-452.

33. Glauser, M.P., G. Zanetti, J.D. Baumegartner, and J. Cohen. 1991. Septic shock: pathogenesis. Lancet. ii:732-739.

34. Beutler, B., and A. Cerami. 1988. The common mediator of shock, cachexia, and tumor necrosis. Adv. Immunol. 42:213-231.

35. Hannun, Y.A., and L.M. Obeid. 1995. Ceramide: an intracellular signal for apoptosis. TIBS (Trends Biochem. Sci.). 20:73-77.

36. Haimovitz-Friedman, A., C.-C. Kan, D. Ehleiter, R.S. Persaud, M. McLoughlin, and Z. Fuks. 1994. Ionizing radiation acts on cellular membranes to generate ceramide and initiate apoptosis. J. Exp. Med. 180:525-535.
37. Jarvis, W.D., R.N. Kolesnick, F.A. Fornari, R.S. Traylor, D.A. Gewirtz, and S. Grant. 1994. Induction of apoptotic DNA damage and cell death by activation of the sphingomyelin pathway. Proc. Natl. Acad. Sci. USA. 91:73-77.

38. González-Amaro, R., C. García-Monzón, L. García-Buey, R. MorenoOtero, J.L. Alonso, E. Yagüe, J.P. Pivel, M. López Cabrera, E. Fernández Ruiz, and F. Sánchez-Madrid. 1994. Induction of tumor necrosis factor $\alpha$ production by human hepatocytes in chronic viral hepatitis. J. Exp. Med. 179:841-848.

39. Ameisen, J.C., J. Eustaquier, and T. Idziorek. 1994. From AIDS to parasite infection: pathogen-mediated subversion of programmed cell death as a mechanism for immune dysregulation. Immunol. Rev. 142:9-52.

40. Singer, G.G., and A. Abbas. 1995. The Fas antigen is involved in peripheral but not thymic deletion of $\mathrm{T}$ lymphocytes in $\mathrm{T}$ cell receptor transgenic mice. Immunity. 1:365-371. 